\title{
STUDENTS' CONSTRAINTS IN READING DESCRIPTIVE TEXT AT MTs USWATUN HASANAH
}

\author{
Novia Wulansari ${ }^{1}$, Sri Supiah Cahyati $^{2}$ \\ 1,2 IKIP Siliwangi \\ ${ }^{1}$ noviawulansari@student.ikipsiliwangi.ac.id, ${ }^{2}$ srisupiahcahyati@ikipsiliwangi.ac.id
}

\begin{abstract}
The aim of the research was to investigate the constraints and ability in Reading comprehension. This research was qualitative research. The subjects were 20 students of Class VII A of MTs Uswatun Hasanah, and they were divided into two groups based on their score. The students getting score above the standard score were grouped in group A; and those getting score under the standard score were in group B. To gain the data, the study employed the Reading test and as the instruments. The data were analyzed by using descriptive analysis. The finding revealed that there was only one student getting high score (above the standard score), while 19 students got low score (under the standard score). Furthermore, the Reading comprehension ability between the students of group A and B was not significantly different and their constraints were relatively similar.
\end{abstract}

Keywords: Constraints, Descriptive Text, Reading Comprehension

\section{INTRODUCTION}

In academic setting, Reading is assumed to be the central means for learning new information and gaining access to alternative explanations and interpretations (Marrianne, 2001: 187). It means that reading stands a basic tool as a means for students to learn new information. All subjects of school lesson provide textbooks as a foundation, so the students should read them if they want to follow the lesson well. In order to understand or to get points of written text, students need comprehension for it. Reading is one of means used for communication between a writer and a reader. According to Grabe and Stoller (2002), reading is an ability to draw meaning from printed page and interpret information appropriately. Cameron (2001) states that reading is actually about understanding, it is not only about understanding the word or code but also understanding the message that is conveyed of the text. In addition, Eskey (2002) also asserts that reading is a complex process, because it involves both consciousness and subconsciousness of the reader. It means that comprehending and interpreting information of a text are important. The reader does not only know the words but also understand the message of the text.

Reading is not as easy as what people think for it requires not only to read series of sentences, but also to understand the content and the purpose of the text. Additionally, reading is also very important in the curriculum of high school. According to Kurikulum 2013 for Junior High School, there are several kinds of reading texts that should be learnt and taught. One of the reading texts for the second grade of junior high school is descriptive text. In reading aspect, the goal of Standard of Competency and Basic Junior High School is being able to comprehend the descriptive text, either in spoken or written form. It can be understood that the second grade students of Junior High School should master reading skill appropriately. However, in reality, learning reading is not something easy for Indonesian students. 
According to ACDP Indonesia (2016), Indonesia is one of 12 countries having signifcantly low scores of international standard. The majority of the students feel difficult to read an English text so it makes them cannot fully understand the content of what they read. This problem probably appears because they lack in mastering vocabulary; as well, poor reading proficiency is a problem for many students due to many reasons. Hellekjaer (2009) reveals that the main problems encountered by students were unfamiliar vocabulary and slow reading. Moreover, reading and vocabulary are strongly connected (Fengning, 2002). As the person improves his skills in one, he improves his skills in the other. An individual with the richest and most vocabulary, however, can read more complicated and varied sources of information easily.

One of the previous researches was did by Zahari et al. (2013). They found that the difficulties the students confronted in reading Rcount text were resulted by some difficulties in terms of (1) finding general and specific ideas that was caused by the limitation of comprehending recount text and having poor vocabularies, (2) comprehending whole text as they did not have sufficient background knowledge as well as they could not activate their background knowledge well, (3) drawing an inference for they had short-term memory about what they read, (4) predicting the meaning of words in recount text as well as they did not have good reading strategies in guessing unfamiliar words, and (5) applying English grammatical rule to discriminate or choose the best answer.

Furthemore, Putra (2010), in his study concerning students' ability in reading English texts, found that the students' reading comprehension in terms of (1) identifying topic of English texts is fair, (2) identifying main idea of English texts is fair, (3) identifying word reference of descriptive texts is good, (4) identifying synonym and antonym of descriptive texts is poor, (5) identifying location information of descriptive texts is good, and (6) identifying inference of descriptive texts is poor. In general, the students ability in reading English texts, averagely, was fair. On the other hand, Fitri (2013) revealed that whatever the kinds of text, as long as its content was unfarmiliar to the participants, they would find difficulties in finding out the main idea in the reading texts and vice versa.

Based on explanation above, it could be inferred that students had problems in reading comprehension, particularly in some aspects of reading, i.e. vocabulary, identify main idea, getting specific information, and inference., therefore, the major purpose of this study was to investigate the constraints and ability of the students having high and low level in reading descriptive text.

\section{METHOD}

This research employed qualitative as the research design. The population of this research was the the first grade students of MTs Uswatun Hasanah ; and from 35 students of class IX A, the writer took 20 students as the participants. The students were then divided into 2 groups, group A for high level and group B for low level. Reading test and interview were employed as the research instrument to collect the data. This research was conducted in two meetings: first meeting for giving reading test intending to see the students' constraints, and the second meeting for undertaking the interview concerning their ability and contraints in doing the given test. To make sure that the data were valid, this study used triangulation. According to Setiyadi (2002), the use of triangulation is to enrich the data and to get more accurate conclusion. 


\section{RESULTS AND DISCUSSION}

\section{Results}

Administering the investigation and data analysis, this research eventually could discovered the recent findings which, definitely, related to the research purpose. Based on the data from the reading test and interview it revealed that the students' constraints on reading comprehension were divided into three aspects of reading, they are: specific information, inference, and vocabulary. It can been seen in the table below.

Table 1. The Specification of Students' Wrong Items in Reading Test

\begin{tabular}{|c|c|c|c|c|c|c|c|}
\hline \multirow[b]{2}{*}{ No. } & \multirow{3}{*}{$\frac{\text { Students' }}{\text { codes }}$} & \multicolumn{5}{|c|}{ Five Aspects of Reading } & \multirow{3}{*}{$\begin{array}{c}\text { Total of } \\
\text { Difficulties }\end{array}$} \\
\hline & & \multicolumn{2}{|c|}{ Main Specific } & \multirow[b]{2}{*}{ Reference } & \multirow[b]{2}{*}{ Inference } & \multirow{3}{*}{ Vocabulary } & \\
\hline & & \multirow[b]{2}{*}{ Idea } & & & & & \\
\hline & & & Information & & & & \\
\hline 1 & FAS & 1 & 2 & 1 & 2 & 3 & 9 \\
\hline 2 & $\mathrm{AW}$ & 1 & 5 & 1 & 4 & 2 & 13 \\
\hline 3 & $D M P$ & 2 & 5 & 1 & 4 & 2 & 14 \\
\hline 4 & MRA & 2 & 4 & 1 & 5 & 3 & 15 \\
\hline 5 & $\mathrm{AP}$ & 1 & 5 & 0 & 3 & 4 & 13 \\
\hline 6 & $\mathrm{CR}$ & 1 & 4 & 0 & 5 & 4 & 14 \\
\hline 7 & $D W$ & 1 & 1 & 0 & 2 & 3 & 7 \\
\hline 8 & SA & 1 & 4 & 1 & 3 & 3 & 12 \\
\hline 9 & $\mathrm{AS}$ & 1 & 5 & 0 & 4 & 6 & 16 \\
\hline 10 & MA & 3 & 3 & 1 & 1 & 4 & 12 \\
\hline 11 & $G F$ & 3 & 6 & 1 & 6 & 5 & 21 \\
\hline 12 & $\mathrm{HN}$ & 2 & 5 & 0 & 5 & 2 & 14 \\
\hline 13 & RK & 2 & 3 & 0 & 5 & 2 & 12 \\
\hline 14 & $\mathrm{SH}$ & 2 & 5 & 1 & 3 & 6 & 17 \\
\hline 15 & MR & 1 & 6 & 0 & 2 & 6 & 15 \\
\hline 16 & FM & 4 & 3 & 1 & 3 & 6 & 17 \\
\hline 17 & $\mathrm{AF}$ & 1 & 3 & 1 & 3 & 2 & 10 \\
\hline 18 & DP & 1 & 5 & 0 & 3 & 2 & 11 \\
\hline 19 & MI & 1 & 3 & 1 & 3 & 2 & 10 \\
\hline \multirow[t]{2}{*}{20} & SIA & 2 & 4 & 0 & 4 & 1 & 11 \\
\hline & Total & 33 & 81 & 11 & 70 & 68 & 263 \\
\hline
\end{tabular}

From Table 1 presented above, it obviously indicates that the students have the problem in three aspects of reading, they are specification information, inference and vocabulary. It can be seen that the most frequent wrong answers are in specific information (81), inference (70), and vocabulary (68) it means the problems that students faced in reading comprehension are finding specific information, making inference, and mastering vocabulary.

In the attempt to answer the research question "What constraints did high and low level students face in reading comprehension?", the researcher conducted reading test and interview. It was aimed to find out the constraints which high and low level students faced in reading comprehension. The interview was administered outside the classroom to avoid the interference from other students and to maintain the concentration of the students being interviewed. 
Based on the data analysis taken from the interview, it revealed the students problems. They are: lack of students' affective factors such as when the teacher teach the material, the students bored when learning, lack of vocabulary knowledge, lack of sentence length when they read, poor reading strategy and lack of understanding five aspects in reading.

Nevertheles, a student stated in the interview also revealed that reading activity was enjoyable. Even though he did not know some vocabularies, he still continued to read the whole text. It means that he was interested in reading English texts though he faced some difficulties in interpreting the entire text due to his poor vocabulary mastery. Then student 2 said that the content of the text given made him lazy to read the text. He argued it was boring to read it and he preferred to take a peek to his friends' work.

In case of vocabulary knowledge, based on the result of interview, student 1 said that many unknown vocabullary appeared in the text so he tried to open the dictionary to found the meaning of word that he didn't know. However, when the same word was asked in different task, he could not remember the meaning of that words because he had problem in memorizing the meanings of words. Then student 2 said that he had a problem in memorizing vocabulary. He said he had difficulties in understanding the meaning of word in a text but he was lazy to open the dictionary because it was wasting time.

In the matter of length of the text, student 1 said that he had problem in identifying main idea and information of the passage containing lots of words because he did not understand the content of the text. Therefore, he had problem in making conclusion of the long text. Student 2 , on the other hand, had similar problem with student 1 yet he had different reason. He thought that the long text made him difficult to determine the answer of the questions asked. He also said long text made him confused about the content because many of vocabularies that he did not understand. In addition, the problem of poor reading strategy, student 1 said that he had a strategy to find information in the text. For example, when he faced questions about main idea in paragraph, he immediately read the paragraph asked then highlighted the words he taught as the answer. He guessed that the answer of main idea was the words which came a lot in paragraph. On the contrary, while facing the same question, student 2 read the whole text repeatedly until he found the answer and to answer the next question, he would read the whole text again to find the answer.

Meanwhile, the problem of poor comprehension of five aspects in reading, student 1 said that he had problems in making inference and understanding vocabulary when he read the text, he didn't understand the content of the text and got confused to made conclusion about the text. It was difficult for him because there were many vocabularies in the text that he didn't understand. Meanwhile, student 2 problem was in finding specific information and making inference. He got confused to make a conclusion by himself because the answer not provided explicitly in the text. He also said he had to read the text repeatedly to answer the questions about specific information and inference because it was difficult to guess the answer.

Based on the research findings, it could be concluced that the students still confused in finding information in the text. They got confused in determining information because they did not knew the meaning of particular words. They could read the descriptive text and answer the questions of the text, but they still lacked of understanding on the meaning of words. This statement is actullay supported by Ningsih (2014) that the students do not understand the English text because of lack of their vocabularies. Thus, they feel bored to reading and cannot get the meaning of the text. 
Table 1. Number of Students Based Early Reading Ability

\begin{tabular}{lll}
\hline PAM & Experiments & Control \\
\hline High & 11 & 12 \\
Medium & 53 & 44 \\
Low & 9 & 10 \\
\hline Total & 73 & 66 \\
\hline
\end{tabular}

\section{Discussion}

As the result of data analysis, it showed that the main problem of sudents in Reading were divided into 5 factors. They were:

(1) students' affective factor, (2) vocabulary knowledge, (3) sentence length, (4) poor reading strategy, and (5) poor understanding five aspects in reading. The first factor was lack of students' factor. In identifying this problem, the writer found that there were several students who had low motivation in learning English so that they hadn't got interest in learning English. The less of motivation was much influenced by inability of the students in reading. The students said that reading was a difficult skill, it happened since the text contained many vocabulary that they didn't know the meaning and it made the students feel bored when they did reading; they hence did not know what they read. This is actually in line with the theory from Guthrie et al. (2007) who that if students' reading interests are weak, their competency grows little and their quality as readers diminishes. It could be emphasized that if the students' have lack of reading interest and motivation it could make them lack of reading skill.

Furthermore, this research also found that the students got confused and could not thoroughly get ideas conveyed by the text because of the unfumilliar words. The lack of vocabulary hindered their comprehension. This finding was in line with Hellekjaer's statement (2009) which revealed that the main problems encountered by students were unfamiliar vocabulary and slow reading. In this research, students 1 and 2 said that they had problem in vocabulary. When reading, they often encountered many unfamiliar words in the text so that it was difficult to comprehend. The next common problem, according to their answers, were content of text, unfamiliar topic and difficulty in memorizing words.

Besides, this research also revealed that the students' lack of vocabulary influenced their reading ability. It is supported by Fengning's theory (2002 that reading and vocabulary are strongly connected. As the person improves his skills in one, he improves his skills in the other. An individual with the richest and most vocabulary, can read more complicated and varied sources of information easily. This statement shows that vocabulary really supports students' reading ability. When the students lack in mastering vocabulary, they will face the difficulty in understanding the texts.

Moreover, it was also found that they had problem in identifying the main idea of the passage of long sentences. This was because they had to consider anything that appeared on the printed text, so the longer the sentence, the more difficult it would be, and the relation of the various parts of the text would be difficult to short out. This statement is supported by Mc Whother (1989) who states that a passage with very long sentences can make reading more difficult and will force a reader to read more slowly. This is also the reason for the students to get the long sentence more difficult compared to the short one. 
In addition, it was found that studentsmostly had problems in understanding five aspects of reading, more specifically, in finding specific information, making inference, and vocabulary. In these aspects, they answered many questions incorrectly if compared with the other aspects. It was supported by Mashulah's study (2013) which found that the majority of the students find difficulties in identifying main idea of the text, more than half of students made mistake in specific information in the text and many students cannot understand the structure of the text. Moreover, Putra (2010) found that the students' ability in identifying inference of descriptive texts is poor while in the other aspects the students' ability is good and fair. As well, this finding was in line with Mauli (2004) who found that being confused on vocabulary knowledge and grammatical rules are the biggest problems in finding main idea of students. It means that finding specific information, making inference, and vocabulary are the problem students' face in common.

Besides analyzing the students' problems in reading, the study also compared the students' ability in comprehending reading texts between low and high level students. The finding showed that the ability between low and high level students did not indicate the specific difference in comprehending reading texts. It was proved by the result of their reading test. Their results indicated that their score in reading test was not significantly different. The results of their answers were quite same but they had different strategy to answer each question. It was proven by the interview which revealed that the students getting high score had better strategy than the students having low score. The students with high score did the guessing technique and opening dictionary in answering the questions; while the students with low score read the whole text repeatedly to answer the question so that they spent too much time to answer one question only. The statement is supported by Sutarsyah (2015) who found that the preliminary research are not very significant, for example, they said that their reading problem was when facing the text containing unknown topic. That means their reading problem deals with insufficient background knowledge.

Refer to the statement above, it is found that the students had problems, especially when they faced academic reading texts. They had difficulty in comprehending unfamiliar reading text. As a consequence, they were not able to answer the questions correctly, especially, in understanding specific information and making inference since they did not understand the topic of the text they read and unfamiliar topic. In addition, they also had difficulty in vocabulary because they did not understand the vocabularies in the text. On the other hand, when they read familiar and interesting topics, they did not find many difficulties to answer the questions correctly.

\section{CONCLUSION}

In line with the discussion of the research findings, some conclusions are drawn as follows:

1. The first grade of MTs Uswatun Hasanah faced 5 problems in understanding English text, they were in terms of lacks (1) students' affection factors, (2) vocabulary mastery, (3) sentence length, (4) reading strategy, and (5) understanding in five aspects of reading.

2. Besides, the ability between the students with low and high levels did not show the specific difference in comprehending reading texts. It was proved by the result of their Reading test which indicated that their score in Reading test were not significantly different. 


\section{ACKNOWLEDGMENTS}

I gratefully thank to the principal of MTs Uswatun Hasanah for allowing me to conduct the research there, to the teachers in MTs Uswatun Hasanah Mrs. Risna for allowing me to conduct my research in her class and supporting me, and for my friend in supporting and sharing. I could not finish this without your great guidance.

\section{REFERENCES}

Cameron, K. (2001). Call and the challenge of chance (Intellect). United Kingdom.

Eskey, D. E. (2002). Reading and the teaching of L2 reading. TESOL Journal, 11(1).

Eskey, R. (2002). Teaching reading to English language learners (A Reflecti). England.

Fengning, Y. (2002). Context clues-a key to vocabulary development. Forum 32.3 (1994), 39, $150-165$.

Fitri, Y. (2013). An analysis of students' difficulties in finding out main idea of English texts at the second year of Madrasah Aliyah Miftahul Huda Terbanggi Besar Lampung Tengah. Lampung University.

Mashulah. (2013). An analysis of students' difficulties in understanding English reading text (case study of descriptive text among the second grade students at MTs Miftahul Ulum, Duriwetan Maduran, Lamongan). Surabaya: State Islamic University of Sunan Ampel.

Mauli, R. (2014). An analysis of students' difficulties in finding main idea of English texts at the second year of Madrasah Tsanawiyah Negeri 1 Lampung Utara. Lampung University.

Mc Whorter, K. (1989a). College reading study skills. London.

Mc Whorter, K. (1989b). Guide to college reading. New York: Harper Collins Publishers.

Putra, M. (2010). Students' dificulties in understanding the reading descriptive text at SMPN 1 Kapur IX Karangrayung. Padang University.

Scott, Foresman and Company Ningsih, S. (2014). A descriptive study of students' difficulties in reading narrative text at eleven grade students of SMA Model Kabila. Gorontalo State University.

Setiyadi, B. (2002). Penelitian dalam pengajaran bahasa asing. Universitas Lampung.

Sutarsyah, C. (2015). Reading theory and practice. Yogyakarta: Graha Ilmu.

Zahari., Rocky., Andi., Afriza., \& W. (2013). An analysis of students' difficulties in reading recount text at SMKN 3 Bengkulu. Bengkulu University. 